\title{
Analisis Akuntansi Sustainabilitas Pada Bisnis Berkelanjutan Perumahan Syariah
}

\author{
Yopi Yudha Utama
}

Fakultas Ekonomi dan Bisnis Islam, IAIN Kediri

*Email korespondensi: yopiyudhautama@iainkediri.ac.id

\begin{abstract}
This study aims to use a case study approach to understand sustainable business practices in Sharia housing projects. The subject of this study is DP, a Sharia real estate. The results show that Sharia developers implemented the sustainability aspect of their business. Economically, the company has succeeded in several ways, both directly and indirectly. From a social perspective, several aspects of labor, human rights and community indicators are taken into accountFrom an environmental point of view, the company includes conformity of products and services, waste, water and energy. On the spiritual level, what the company does for employees, employees and their surroundings meets existing aspects. The results of this study indicate that PD business practices can create a truly sharia housing concept.
\end{abstract}

Keywords : Economic, social, environmental, spiritual, sharia housing

Saran sitasi: Utama, Y. Y. (2021). Analisis Akuntansi Sustainabilitas Pada Bisnis Berkelanjutan Perumahan Syariah. Jurnal Ilmiah Ekonomi Islam, 7(02), 560-570. doi: http://dx.doi.org/10.29040/jiei.v7i2.2511

\section{DOI: http://dx.doi.org/10.29040/jiei.v7i2.2511}

\section{PENDAHULUAN}

Ekonom asal Amerika, Friedman (1970) mengungkapkan bahwa "satu-satunya pertanggungjawaban sosial dalam bisnis adalah penggunaan sumber daya dan segala kegiatan yang terlibat di dalamnya dirancang untuk meningkatkan keuntungan". Pernyataan yang diungkapkan Friedman tersebut seakan-akan hanya keuntungan saja yang perlu diperhatikan oleh setiap aspek yang ada di dalam perusahaan. Padahal sebagaimana yang kita ketahui, jika yang menjalankan perusahaan merupakan manusia, dan pasti akan berhubungan dengan manusia lain dan juga dengan alam. Tanpa adanya interaksi sosial dengan stakeholders serta masyarakat di dalam pandangan paradigma bahasa Habermas, maka perusahaan tidak akan dapat berdiri (Dewi, 2010). Laba sebagai orientasi dari kapitalisme, tidak memberikan kontribusi dalam peningkatan kemakmuran, tetapi justru menimbulkan kerusakan pada keseimbangan hidup manusia melalui stimulasi pengembangan potensi ekonomi secara berlebihan dan terjadinya penurunan kondisi sosial (Galtung dan Ikeda, 1999; Rich, 1996; dalam Chwastiak, 1999). Dalam hal ini berarti adalahgagalnya dimensi materi dalam mewujudkan keharmonisan hidup, sehingga perluadanya faktor lain sebagai penyemibang dimensi materi.

Perusahaan dinilai memiliki peran yang penting dalam membentuk kehidupan yang harmonis. Maka dari itu, perusahaan tidak seharusnya hanya memperhitungkan untuk mendapatkan keuntungan ekonomis saja dan mengesampingkan lainnya, melainkan harus juga memperhatikan keadaan sosial di lingkungan perusahaan dan juga memperhatikan kelestarian lingkungan. Dalam artian, kinerja keuangan perlu diseimbangkan dengan kinerja sosial, dan juga upayanya dalam pelestarian alam, agar terjadi kehidupan yang nyaman dan harmonis. Inilah yang diinginkan oleh sebuah konsep keberlanjutan. Keberlanjutan bermakna mampu untuk menjaga dan mengelola stabilitas ekonomi atau sumber daya tanpa merusak sumber daya alam yang berdampak pada waktu yang akan datang (Collins-Ins, 2006 dalam Guo \& Yang, 2014).

Menurut Mitchell et al.(2008) sustainability merupakan seperangkat nilai, permasalahan, dan proses yang harus dilakukan oleh perusahaan untuk meminimalisasikan kerusakan dari kegiatan operasionalnya. Sustainability sendiri juga dapat dimaksudkan dengan corporate social responsibilty 


\section{Jurnal Ilmiah Ekonomi Islam, 7(02), 2021, 561}

dalam penelitian akuntansi (Guo \& Yang, 2014). Sedangkan Finch (2005) menyebutkan jika CSR merupakan bagian dari keberlanjutan itu sendiri, dimana CSR hanya berfokus pada tujuan jangka pendek perusahaan, sedangkan sustainability berfokus pada tujuan perusahaan jangka panjang perusahaan yang ingin dicapai.

Sustainability sangat terikat dengan konsep tripple bottom line, karena konsep ini berkembang atau sebagai langkah awal pengembangan untuk kegiatan pengidentifikasian dan pemantauan yang berkontribusi terhadap sustainability (Stenzel, 2010; Felisia \& Limijaya, 2014). Tripple bottom line merupakan konsep yang mendukung adanya keselarasan antara aspek ekonomi, sosial, dan lingkungan. Konsep ini digagas pertama kali oleh Elkington (1997). Elkington (2004) dengan konsepnya, triple bottom-line, memberikan pandangan jika sebuah perusahaan ingin mempertahankan kelangsungan hidupnya, maka perusahaantersebut harus memperhatikan " $3 \mathrm{P}$ " yaitu profit, people, dan planet. Pernyataan tersebut berarti bahwa selain mengejar keuntungan (profit), perusahaan juga harus memperhatikan dan terlibat pada pemenuhan kesejahteraan masyarakat (people) dan turut berkontribusi aktif dalam menjaga kelestarian lingkungan (planet). Smythe (2014) juga menyatakan jika konsep di dalam sustainability merupakan tiga dimensi yang mengintegrasikan antara faktor ekonomi, sosial dan lingkungan sebagai perencanaan dan pengambilan keputusan. Apabila perusahaan dapat menyelaraskan ketiga komponen tersebut, maka perusahaan akan diterima secara baik oleh masyarakat dan lingkungan sehingga keberlanjutan perusahaan dalam jangka panjang dapat terjamin.

Selain triple bottom line, juga ada konsep keberlanjutan lain yaitu sustainability accounting. Konsep ini digagas oleh Sukoharsono (2010), dimana dalam konsep akuntansi sustainabilitasnya melibatkan dimensi spiritual di dalamnya, sehingga disebut sebagai quadrangle bottom line. Spiritual merupakan faktor yang sangat penting dalam kehidupan. Spiritual sendiri juga sebagai upaya dalam proses pembangkitan kesadaran ketuhanan, sehingga mampu menerapkan terciptanya keseimbangan kehidupan dunia dan akhirat. Dengan demikian, maka dapat dipahami jika segala sesuatu terdapat pertanggungjawabannya, sehingga haruslah terikat pada nilai-nilai. Dalam Islam, keseimbangan dunia dan akhirat bukan berarti pemenuhan terhadap kebutuhan di dunia tidak terkait sama sekali dengan aturan-aturan agama. Oleh karena itu, meskipun setiap individu memenuhi kebutuhan hidupnya di dunia harus didasarkan pada aturan-aturan agama.

Penulis memandang jika adanya dimensi spiritualitas dalam konsep akuntansi sustainabilitas, diharapkan mampu mengikis rasa egoisme dari orangorang yang tidak beratnggungjawab didalam perusahaan tersebut. Egoisme merupakan salah satu nafsu buruk yang harus terus diperangi. Ego merupakan akar permasalahan dan setiap individu harus meminimalisir bahkan sampai melenyapkan ego tersebut (Molisa, 2011; Efferin, 2015). Dengan meminimalisir egoism tersebut, diharapkan perusahaan tersebut akan terus melakukan kegiatan operasionalnya berada di jalan yang benar, jalan yang memiliki kebermanfaatan bagi semua kalangan atau semua pihak, jalan yang diridloi oleh Allah subhanahu wa ta'ala.

Pemaparan yang telah disebutkan pada beberapa paragraf di atas, penelitian ini dilakukan pada perumahan syariah. Hal ini dipilih oleh peneliti, agar peneliti memahami bagaimana sustainability business yang dijalankan oleh perumahan syariah tersebut. Mengapa harus perumahan syariah? Karena perumahan yang membawa konsep syariah di dalamnya, maka segala operasional perusahaan seharusnya dapat membawa kemaslahatan secara umum atau bagi semua pihak. Hal ini selaras dengan yang diungkapkan oleh Zhu \& Lin (2004) dan Zhang (2015), yaitu industri pembangunan dan perumahan memiliki dampak yang signifikan terhadap lingkungan sosial dalam beberapa aspek, termasuk juga terhadap lingkungan alam maupun ekonomi.

\section{METODE PENELITIAN}

Penelitian ini menggunakan pendekatan case study sebagai metodologi penelitiannya. Studi kasus merupakan sebuah penyelidikan secara menyeluruh yang menyelidiki suatu fenomena yang sekarang terjadi dalam natural setting (Harling, 2002).

Kelebihan studi kasus menurut Aziz (dalam Ulfatin, 2015:55) diantaranya adalah (1) memberikan informasi penting mengenai hubungan antar variabel serta proses-proses yang memerlukan penjelasan dan pemahaman yang lebih luas; (2) adanya kesempatan untuk memperoleh wawasan mengenai konsepkonsep dasar manusia, dan melalui penyelidikan yang intensif, peneliti bisa menemukan karakeristik dan 
hubungan yang (mungkin) tidak diharapkan atau tidak diduga sebelumnya; (3) menyajikan data dan temuan yang sangat berguna dalam rangka pengembangan ilmu-ilmu sosial.

\section{Lokasi Penelitian}

Penelitian ini mengambil studi pada perumahan Islami yang terdapat di kota Malang. Perumahan yang dijadikan objek penelitian ini identitasnya peneliti samarkan menjadi Perumahan Islami DP. Alasan pengambilan studi pada perumahan Islami adalah karena perusahaan ini juga mengawali kegiatannya usahanya dengan membuka lahan baru. Perusahaan yang bernafaskan syariah tidak boleh hanya namanya saja yang ada embel-embel syariah, namun segala operasionalnya juga harus sesuai dengan syariat Islam. Dengan alasan yang demikian, maka kegiatan operasional yang dijalankan oleh perumahan Islami harus selaras antara pencarian keuntungan maupun dengan pelestarian alam maupun lingkungan sosial. Maka perusahaan perumahan Islami harus berusaha semaksimal mungkin menciptakan kemaslahatan secara umum.

\section{Informan Penelitian}

Informan penelitian ini adalah seseorang yang memiliki kewenangan di perusahaan tersebut dalam membuat keputusan. Pemilihan informan tersebut dipilih karena seseorang yang memiliki kewenangan dalam pembuat keputusan, maka seseorang tersebut paling tidak harus mengetahui segala akibat dari dampak keputusan yang diambil. Tentu hal ini bukan sebuah posisi yang sembarangan. Selain itu, pemilihan informan juga sesuai dengan asal tujuan dari penelitian ini, yaitu adalah untuk memahami atau mengetahui bisnis keberlanjutan dari real estate atau perumahan Islami dengan menggunakan pendekatan akuntansi sustainabilitas berdimensi spiritualitas.

Jumlah informan yang dijadikan oleh peneliti adalah dua orang, yaitu Pak Dn dan Pak So. Informan penelitian yang berjumlah dua ini karena ijin yang diberikan oleh direktur utama yaitu Pak DN, yang juga sekaligus menjadi informan peneliti. Sementara itu, di dalam perusahaan tersebut, Pak So menajabat sebagai kepala bagian produksi.

\section{Teknik Pengambilan Data}

Teknik pengambilan data ini menggunakan wawancara dan observasi. Wawancara yang dilakukan dalam penelitian ini berada di kantor informan. Selain itu juga dilakukan dengan pendokumentasan. Dokumentasi merupakan teknik pengumpulan data pendukung yang dilakukan peneliti. Praktik dokumentasi yang dilakukan dalam penelitian ini yaitu dokumentasi semua hasil observasi baik berupa catatan, maupun rekaman suara informan.

\section{Teknik Analisis Data}

Teknik analisis data merupakan suatu langkah yang digunakan peneliti dalam memulai pencarian data sampai menerjemahkan isi data tersebut. Sebagaimana Sugiyono (2015: 89) menjelaskan jika tahap-tahap yang perlu dilakukan dalam analisis data pada penelitian kualitatif dimulai sejak tahap pendahuluan, yaitu sebelum berada di lapangan, lalu ketika di lapangan, dan setelah menyelesaikan proses di lapangan.

\section{Rancangan Kegiatan}

penelitian memuat informasi berupa gambaran oenelitan yang disusun oleh peneliti sampai menghasilkan sebuah informasi yang disajikan kepada para pembaca dari hasil atau proses penelitian. Berikut alur penelitian di dalam penelitian ini:

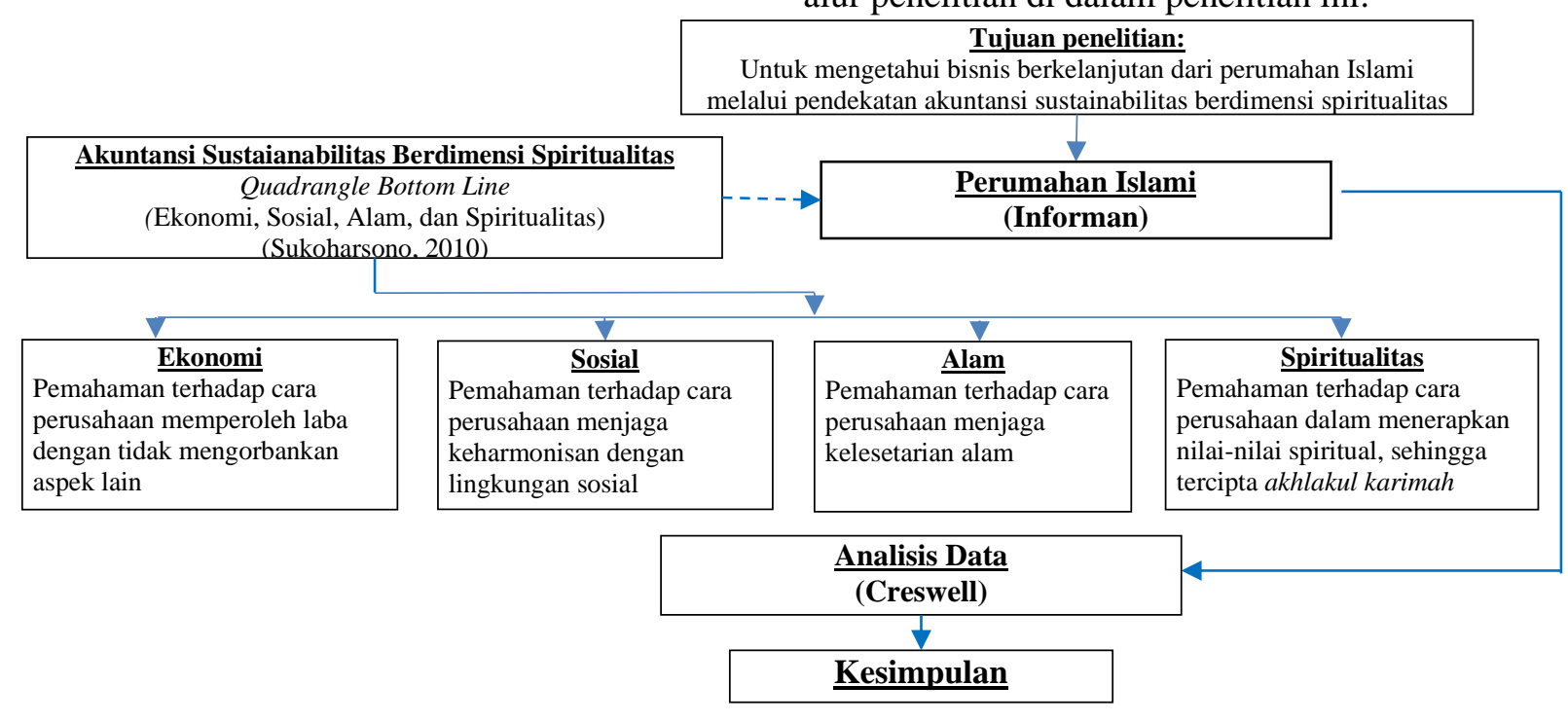

Gambar 1. Rancangan Kegiatan 


\section{Jurnal Ilmiah Ekonomi Islam, 7(02), 2021, 563}

\section{HASIL DAN PEMBAHASAN}

\subsection{Perumahan Islami DP}

Perumahan Islami DP dibangun dengan tujuan sebagai solusi bagi masyarakat untuk memiliki perumahan tanpa riba. Berikut penuturan Pak DN selaku direktur utama perumahan ini:

"Sebagai solusi bagi masyarakat untuk kepemilikan rumah tanpa riba dan sebagai media dakwah untuk menyadarkan kepada masyarakat bahaya riba"

Tujuan didirikannya perumahan berdasarkan informsi yang penulis penulis peroleh dari Pak DN adalah untuk menghindari riba. Hal ini dikarenakan riba merupakan hal yang dilarang, seperti yang terdapat dalam Al-Qur'an dan Hadits. Diantaranya di dalam AL-qur'an adalah bunyi ayat 130 pada Q.S AliImron

"Hai orang-orang yang beriman, janganlah kamu memakan riba dengan berlipat ganda dan bertakwalah kamu kepada Allah supaya kamu mendapat keberuntungan"

Riba memiliki dampak yang berbahaya, karena hukuman bagi pelaku riba adalah ancaman siksa api neraka. Maka dari itu setiap orang harus dan wajib menghindari riba, agar hidupnya selamat dan beruntung baik di dunia maupun di akhirat nantinya. Oleh karena itu, tujuan didirikannya perusahaan merupakan tujuan yang mulia.

Perumahan ini memiliki 99 Unit, yang terdiri dari empat tipe perumahan. Tipe-tipe perumahan tersebut antara lain adalah tipe perumahan Abu Bakar AshShiddiq (80/88), Umar Bin Khotob (70/84), Usman Bin Affan (48/81), Ali Bin Abi Thalib (70/72).

Perusahaan menggunakan nama-nama sahabat Nabi Muhammad SAW tersebut karena memiliki alasan. Alasan tersebut diungkapkan oleh Pak DN, yaitu sebagai berikut:

"Menggunakan nama-nama sahabat sebagai syiar mas sekaligus mengenalkan kepada masyarakat nama-nama sahabat. Mengingat sekarang banyak yang mulai asing dengan nama-nama sahabat, lebih familiar dengan nama artis, atlit, dll"

Penggunaan nama-nama sahabat pada masing tipe-tipe rumah di perumahan tersebut memiliki manfaat tersendiri. Terutama bagi anak-anak penghuni perumahan tersebut, namun tidak tertutup kemungkinan juga untuk orang tuanya (yang adanya kemungkinan lupa). Untuk anak-anak, yang mungkin mereka lupa atau tidak tahu nama-nama sahabat Nabi
Muhammad SAW, dikarenakan mungkin mereka lebih familiar dengan nama-nama artis dan sebagainya seperti yang diungkapkan oleh pak DN. Selain itu, pemberian nama-nama tersebut menurut penulis juga mengingatkan tentang jasa-jasa mereka di dalam penyebaran agama Islam. Dengan demikan, diharapkan dapat mencontoh perilaku-perilaku yang ditunjukkan oleh para sahabat Nabi Muhammad SAW tersebut.

Untuk memiliki rumah di perumahan DP, calon pembeli bisa melakukan pembayaran baik secara tunai maupun secara kredit. Pembayaran baik tunai maupun kredit tidak dilakukan di bank, namun langsung di kantor perumahan tersebut. Jika pembeli tersebut melakukan secara tunai, dan mungkin setelah rumah tersebut ditempati namun pembeli tidak bisa meneruskan cicilannya, maka pembeli dan perusahaan akan bekerja sama untuk menjual unit rumah yang ditempati tersebut. Setelah rumah tersebut dapat terjual, maka pembeli yang tidak bisa melunasi cicilannya tersebut, seluruh dananya yang telah dibayarkan kepada perusahaan akan dikembalikan $100 \%$. Jadi tidak ada sita-menyita di dalam praktek perumahan yang diterapkan oleh perusahaan tersebut.

Di perumahan islami DP, sayangnya unit-unit yang tersedia di perumahan tersebut hanya bisa dimiliki oleh orang yang beragama Islam saja, jadi bagi orang-orang yang beragama selain Islam tidak boleh membeli di perumahan tersebut. Seharusnya orang non-muslim itu diperbolehkan membeli rumah di perumahan tersebut, karena mungkin dengan membeli rumah di situ nanti siapa tahu dia tertarik untuk mempelajari agama Islam. Hal ini disebabkan terdapat banyak kegiatan agama yang dilakukan di perumahan tersebut, berdasarkan pengakuan Pak DN. Dengan begitu, bisa saja orang tersebut dapat hidayah dari Allah SWT, sehingga menjadi mualaf.

\subsection{Dimensi Ekonomi: Mengurangi Kemiskinan dan Pengangguran}

Perumahan Islami DP ini dalam menjalankan salah satu bisnis keberlanjutannya, dalam hal ini di dalam dimensi atau aspek ekonomi, mereka berbagi kebahagiaan bersama. Hal tersebut terwujud dalam wawancara penulis dengan salah satu informan yang menjabat pada posisi direktur utama dalam perusahaan tersebut, yaitu Pak DN. Berikut ini adalah jawaban beliau yang penulis saring, ketika penulis menanyakan tentang porsi tertentu untuk didonasikan atau didistribusikan kepada masyarakat atau pihak yang membutuhkan: 
"Kalau sejauh ini belum ada porsi khusus, nanti mungkin akan kita rencanakan. Yang pasti nanti yang wajib dulu, yang wajib itu kan zakat mal itu ya, zakat mal dari perusahaan. Nanti akan kita hitung. Kalau porsi khusus tidak ada, artinya tidak kita anggarkan berapa persen, cuman biasanya kita berikan sesuai momen atau keperluan, seperti misalnya kita setiap hari Jum'at memberi makan kepada semua pekerja yang di lapangan, terus biasanya kalau ada kebutuhan-kebutuhan misalkan ada masjid di lingkungan kita seperti renovasi ringan, itu kita bantu dari tenaga kita, atau masjid mungkin butuh seperti pagar itu biasanya kita baik bantu tenaga kita dan bahan ataupun mungkin kita memberi harga murah."

Dari penjelasan Pak DN, maka dapat diperoleh informasi jika belum ada porsi tertentu atau porsi khusus untuk memberikan donasi kepada masyarakat atau pihak yang membutuhkan. Namun, dari jawaban beliau, dapat diartikan jika perusahaan akan senantiasa membantu masyarakat atau pihak-pihak yang membutuhkan seperti memfasilitasi tenaga kerja dan bahan baku untuk memperbaiki masjid. Untuk kedepannya, kemungkinan perusahaan akan memberikan porsi tertentu mengingat dari jawaban Pak DN tadi terdapat pernyataan yang kemungkinan akan merencanakan porsi khusus, sehingga dengan adanya porsi khusus atau tertentu, maka donasi tersebut menjadi rutinitas tersendiri bagi perusahaan perumahan syariah tersebut.

Donasi atau sumbangan berupa penyediaan jasa tenaga kerja atau penyediaan bahan baku yang dikeluarkan oleh perusahaan, tentu bukanlah hal yang mudah dilakukan oleh perusahaan. Mengapa? Karena, pendapatan yang dihasilkan oleh perusahaan, tentunya dihasilkan dari kontribusi semua pihak yang terlibat di dalam perusahaan. Butuh kristalisasi keringat dari pihak-pihak tersebut untuk mewujudkan atau mendapatkan keuntungan bagi perusahaan. Tentu kalau pihak-pihak tersebut tidak berpikir jernih, maka sumbangan yang diberikan kepada pihak yang membutuhkan meskipun sedikit akan terasa menjadi sangat berat. Berbeda jika orang-orang di dalam perusahaan tersebut memiliki pemikiran yang jernih maupun perasaan yang peka. Mereka meskipun memberikan sumbangan dalam jumlah yang besar, tentu akan terasa ringan.
Bantuan dari perusahaan perumahan syariah tersebut yang terdiri dari penyediaan tenaga kerja maupun bahan baku secara gratis ataupun bahan baku yang disediakan dengan harga murah, dapat mempererat hubungan antar perusahaan maupun dengan warga sekitar. Bantuan tersebut juga akan menimbulkan perasaan senang dari warga ke perusahaan perumahan tersebut. Tidak hanya warga, perusahaan perumahan tersebut tentunya juga merasa senang karena pendapatan yang dihasilkan oleh perusahaan, sebagiannya dapat digunakan untuk membantu masyarakat sekitar lingkungan perusahaan tersebut.

Tidak hanya bantuan dana berupa penyediaan tenaga kerja dan bahan baku, perusahaan perumahan syariah juga berupaya untuk meningkatkan perekonomian warga sekitar. Upaya perusahaan perumahan dalam membantu atau berkontribusi dalam meningkatkan perekonomian warga sekitar, adalah dengan menerima pekerja pada posisi tertentu untuk menjadi karyawan di perusahaannya. Adanya kesempatan bagi warga sekitar tersebut, melalui rekomendasi RW setempat ini penulis ketahui setelah menanyakan tentang yang pada intinya adalah perekrutan karyawan. Berikut jawaban dari Pak DN:

"Tergantung, jika ada posisi tertentu seperti pos satpam atau kemanan kita bisa mempekerjakan masyarakat lokal, atau ada titipan dari RW setempat, merekomendasikan warganya itu kita terima, mungkin untuk kebersihan atau kemanan itu masih bisa kita upayakan ada warga sekitar"

Dari apa yang telah dijelaskan oleh Pak DN, maka dapat dilihat jika perusahaan perumahan syariah tersebut menerima secara terbuka dari warga sekitar yang ingin menjadi karyawan pada perusahaan tersebut. Namun, perusahaan tetap memberikan batasan dalam menerima karyawan dari warga sekitar tersebut, maksudnya adalah perusahaan perumahan tersebut akan melakukan selekesi calon karyawan dari warga sekitar yang memiliki kualifikasi sesuai dengan permintaan perusahaan pada posisi profesional tertentu. Bagi warga yang mungkin pendidikannya tidak sesuai dengan syarat permintaan minimal perusahaan maka dipersilahkan untuk melamar pada posisi tertentu saja, seperti pada petugas kebersihan atau kemanan. Untuk karyawan profesional seperti tim keuangan misalnya, perusahaan perumahan tersebut tetap melakukan seleksi pada calon karyawan 


\section{Jurnal Ilmiah Ekonomi Islam, 7(02), 2021, 565}

sesuai dengan kualifikasi yang diinginkan oleh perusahaan.

Diatas persyaratan pendidikan maupun pengalaman kerja yang telah ditetapkan oleh perusahaan, ternyata mereka lebih mengutamakan akhlak dari calon karyawannya, dan juga rajin sholat maupun baca Al-Qur'an. Hal ini dapat dipahami, mengingat perusahaan bergerak dalam nafas yang Islami, sehingga mereka mengutamakan persyaratan seperti itu. Dengan rajin sholat dan baca Al-Qur'an maka diharapkan mereka akan terus ingat terhadap Allah SWT, sehingga akan bekerja dengan penuh tanggung jawab, karena segala sesuatu yang telah mereka kerjakan pasti akan dimintai pertanggungjawaban di akhirat kelak

"Tetapi untuk tenaga yang profesional, ya kita terima sesuai dengan kualifikasi dan kemampuannya. Yang terutama kita pentingkan sih, harus sholat lima waktu, rajin baca Al-Qur'an, jadi kita utamakan dari sisi akhlaknya"

Adanya kualifikasi yang ditetapkan oleh perusahaan, bukan berarti pihak perusahaan membatasi warga sekitar yang ingin menjadi karyawannya. Hal itu dilakukan karena agar karyawan yang menduduki posisi tersebut, mampu menjalankan tugasnya dengan baik dan bertanggung jawab dengan tugasnya tersebut.

\subsection{Dimensi Sosial: Korelasi Perusahaan dan Kesejahteraan Karyawan serta Kepedulian terhadap Masyarakat}

Keselamatan maupun kesehatan dari para karyawan harus diperhatikan oleh perusahaan. Bahkan sudah semestinya, hal itu yang menjadi program pioritas dari perusahaan. Sebagaimana yang telah diketahui, jika keselamatan dan kesehatan memiliki nilai yang tidak dapat diukur. Andaikan perusahaan mengabaikan keselamatan maupun kesehatan para karyawan, tentu hal itu juga berdampak buruk bagi perusahaan. Perusahaan akan mengalami kerugian, baik dari segi kuantitatif maupun kualitatif. Sebagai upaya untuk menyejahterakan karyawannya, mereka memberikan fasilitas klaim tanpa ada premi, seperti yang diungkapkan oleh Pak DN. Berikut jawaban beliau:

"Memberikan fasilitas klaim langsung ke kantor, nanti nilainya tentunya sesuai dengan kebijakan perusahaan, tergantung dari masa bakti, posisi dan jabatan. Dan itu tidak ada premi, artinya tidak mengurangi gaji mereka, jadi murni dari perusahaan."

Dengan adanya faslitas klaim yang memang murni pemberian dari perusahaan, maka perusahaan telah menunaikan salah satu dari hak para karyawan. Tetapi meskipun nilai dari fasilitas klaim tersebut tergantung kebijakan perusahaan, seperti masa bakti, posisi maupun jabatan mereka di perusahaan, hal itu dapat dinilai sebagai sebuah keadilan, mengingat jika mungkin ada karyawan pada posisi yang sama namun beda jumlah masa baktinya dan kedua karyawan tersebut di beri nilai klaim yang sama, maka akan terasa tidak adil bagi karyawan yang telah mengabdi lama di perusahaan tersebut.

Program fasilitas klaim yang dimiliki dan diberikan oleh beberapa perusahaan kepada para karyawannya, mungkin ada yang memotong nilai gaji mereka dalam proses pemberian klaim tersebut. Jika klaim tersebut terdapat pemotongan gaji atau premi misalnya, maka tentu akan merugikan bagi pihak karyawan. Namun, hal ini berbeda dengan apa yang diterapkan oleh perusahaan perumahan Islami yang peneliti jadikan objek penelitian.

Fasilitas klaim perusahaan perumahan islami tersebut, dalam prosesnya tidak akan mengurangi gaji mereka, oleh karena itu pemberian fasilitas klaim tersebut benar-benar murni pemberian dari perusahaan. Meskipun hal itu tergantung dengan beberapa kebijakan perusahaan yang telah disebutkan di paragraf sebelumnya. Dengan tidak adanya premi, maka karyawan menjadi lebih tenang karena mereka dapat mengajukan klaim jika terjadi kecelakaan kerja misalnya, tanpa mengurangi salah satu hak mereka, yaitu berupa gaji.

Kesejahteraan karyawan selain dengan memperhatikan keselamatan maupun kemanan mereka, juga dapat dilakukan dengan pemberian atau perluasan wawasan. Perusahaan mencoba untuk menambah wawasan mereka sesuai dengan bidang yang karyawan tersebut kuasai atau karyawan pada posisi dimana ia bekerja. Caranya adalah dengan mengikutkan mereka pada pelatihan atau seminarseminar tertentu. Berikut jawaban dari Pak DN mengenai hal tersebut:

"Pasti ada pelatihan, misalkan ada marketing

kalau ada seminar tenteng marketing nanti kita ikutkan, untuk manajamen ada pelatihan misalkan ada pelatihan bagaimana membangun tim, membangun bisnis yang bagus, akunting juga misalkan ada training 
ttg perhitungan pajak kita ikutkan. Jadi masing-masing karyawan, kita ada porsi untuk mengikuti training sesuai dengan jabatan mereka. Yang di IT design, kita ikutkan"

Dalam jawaban yang diberikan oleh Pak DN dapat diketahui jika untuk meningkatkan kemampuan karyawan adalah dengan memberikan pelatihan atau seminar. Pelatihan maupun seminar tersebut diberikan kepada karyawan sesuai jabatan mereka. Pelatihan maupun seminar ini diberikan oleh perusahaan, dengan tujuan tertentu. Pak DN menyebutkan misalnya

"Kalau ada seminar tenteng marketing nanti kita ikutkan, untuk manajamen ada pelatihan misalkan ada pelatihan bagaimana membangun tim, membangun bisnis yang bagus"

Dari maksud pernyataan tersebut maka diharapkan karyawan tersebut akan lebih memiliki kemampuan yang lebih baik dari sebelum ada pelatihan tersebut dilaksanakan. Hal itu juga berlaku untuk posisi-posisi yang lain.

Adanya pelatihan maupun seminar merupakan hal yang penting untuk diikuti. Hal ini dikarenakan para karyawan memiliki tambahan ilmu dari adanya program tersebut. sebagaimana yang kita ketahui, ilmu merupakan hal yang sangat penting untuk dimiliki oleh manusia, karena orang berilmu memiliki derajat yang tinggi. Dengan ilmu, maka karyawan dapat membedakan mana pekerjaan yang baik dan yang buruk, mana yang salah dan mana yang benar. Selain itu, mereka juga mampu untuk memilih mana pekerjaan yang efisien dan efektif dengan pekerjaan yang tidak efisien dan efektif. Lalu, ilmu yang mereka miliki nantinya juga dapat dimanfaatkan, salah satu contohnya adalah dengan mengajarkan ilmu tersebut kepada pegawai baru yang masih awam dengan cara kerja perusahaan. Tidak hanya berhenti sampai disitu, dengan ilmu yang mereka punya, mungkin juga bisa membuka kursus untuk masyarakat sekitar tempat tinggalnya, sehingga masyarakat disekitar tempat tinggalnya juga mampu untuk berbisnis dengan baik dan sebagainya. Dengan demikian, karyawan tersebut mampu memberikan kontribusi dalam membangun sumber daya manusia di lingkungan tempat dia tinggal.

Tidak hanya pada karyawan, perusahaan juga berupaya untuk meningkatkan kepedulian terhadap masyrakat sekitar. Objek perusahaan yang terletak di tengah-tengah masyarakat, maka sudah pasti akan bersinggungan dengan masyarakat juga. Tidak mungkin, jika perusahaan tersebut tikda memiliki hubungan dengan masyarakat. Sebagai contohnya adalah jika adanya dampak negatif yang timbul akibat kegiatan operasional perusahaan, maka masyarakat yang terkena imbasnya. Apabila perusahaan tidak bertanggungjawab terhadap masalah ini, maka dapat dipastikan jika perusahaan tersebut tidak akan bisa bertahan lama.

Usaha perusahaan perumahan Islami dalam penelitian ini dalam mengontrol kegiatan operasinya yang memungkinkan berdampak kepada masyarakat setempat, adalah sebagai berikut:

"Akan ada komunikasi RT RW sampai kelurahan setempat. Jadi dari awal, pasti perumahan ada dampak lingkungan lingkungan dan sosial, mulai dari kita pengkondisian lapangan untuk lingkungan projek itu pasti berdampak kepada masyarakat"

Dari jawaban Pak DN diatas maka terlihat jika perusahaan sudah menyadari mengenai dampakdampak yang timbul dari aktivitas perusahaannya. Sebagai antisipasi maupun peristiwa yang telah terjadi, maka mereka melakukan pengkondisian lingkungan proyek perusahaan. Oleh karena itu jika mungkin kegiatan perusahaan sekiranya mengganggu kenyamanan masyarakat, maka kemungkinan perusahaan akan bertindak sebagaimana mestinya.

Masih terkait dengan kontrol kegiatan operasi perusahaan terhadap masyarakat, Pak DN juga menjelaskan jika perusahaan akan ikut berkontribusi dalam acara-acara yang diselenggarakan oleh masyarakat setempat, seperti agustusan, tasyakuran dan lain sebagainya sebagai bentuk kompensasi akibat adanya kegiatan perusahaan di lingkungan masyarakat setempat. Berikut penjelasan dari Pak DN:

"Biasanya dari pihak mereka meminta kompensasi lah, pasti itu ada. Jadi misalkan ada acara kegiatan di rt rw, tasyakuran, agustusan, tentu kita ikut memberikan bantuan. Jadi kita menjaga komunikasi lah pada rt rw setempat"

Adanya kontribusi yang diberikan oleh perusahaan perumahan sebagai kompensasi, menunjukkan jika perusahaan perumahan benar-benar berkomitmen untuk membangun hubungan dengan masyarakat setempat. Hal itu dilakukan atau ditunukkan dengan upaya perusahaan perumahan 
menjaga komunikasi dengan pejabat masyarakat setempat, yaitu baik dengan RT maupun RW.

Membangun silaturahmi dengan masyarakat setempat harus dilakukan oleh perusahaan perumahan, agar terjalin hubungan yang harmonis diantara kedua pihak. Menurut penulis, hubungan harmonis diantara kedua belah pihak dapat menimbulkan manfaat, diantaranya adalah seperti yang telah disebutkan dalam bebrapa paragaraf diatas, yaitu adanya kemudahan bagi masyarakat dalam menjadikan perusahaan sebagai salah satu donatur dalam kegiatan yang diselerenggarakan oleh perusahaan, adanya kesempatan bekerja di dalam perusahaan bagi warga masyarakat setempat yang berpendidikan rendah. Sedangkan bagi perusahaan, kemungkinan manfaat yang dapat diambil adalah dipercayanya perusahaan perumahan oleh masyarakat.

\subsection{Dimensi Lingkungan}

Perusahaan perumahan dapat dikatakan sebagai perusahaan yang juga membutuhkan air untuk pengairan bagi warga yang tinggal di dalam perumahan perusahaan tersebut. Oleh karena itu, air yang diambil untuk pengairan harus memperhatikan kondisi air agar tidak menganggu kestabilitasan air di lingkungannya. Berikut informasi yang penulis peroleh tentang air yang berada di perumahan tersebut:

"Sumber air, kita mengambil sistem PDAM. Jadi disini untuk nimbanya sangat minim, dan sesuai irigasi yang ada. Dan disini itu pernah terjadi berbatasan dengan lahan persawahan di warga, itu yang berbatsan dengan tembok perumahan kita itu kita buatkan saluran air, kita buatkan gorong-gorong yang terbuka. Fasilitas menggunakan PDAM, dan juga sumur bor tapi dalam skala rumah tangga, jadi tidak sangat menganggu kestabilitasan air di sekitar"

Berdasarkan wawancara di atas, perusahaan dalam upayanya untuk menjaga keberlanjutan perusahaan, dibuatkan saluran air yaitu goronggorong terbuka pada saat ada kejadian atau peristiwa berbatasan dengan lahan persawahan warga. Mungkin gorong-gorong ini dibuat agar tidak mencemari air sebagai irigasi persawahan bagi warga di luar perumahan perusahaan tersebut, sehingga air yang mengalir ke persawahan warga sekitar masih air yang terjaga kebersihan mapun kesehatannya. Hal itu penting untuk dilakukan, mungkin dengan pertimbangan jika lahan persawahan tersebut merupakan sumber mata pencaharian utama dari pemiliknya. Apabila gorong-gorong tersebut tidak dibuat, mungkin bisa saja air yang mengalir ke persawahan tidak lancar, kondisi air dapat merusak lahan persawahan sehingga terjadi gagal panen misalnya, sehingga perusahaan dapat merusak roda perekonomian bagi warga pemilik persawahan tersebut. Akibatnya, tidak hanya pemilik persawahan tersebut yang rugi, namun perusahaan juga pasti ikut mengalami kerugian.

Perusahaan perumahan Islami sendiri dari pengairannya menggunakan sistem PDAM, meskipun fasilitas di perumahan tersebut juga menggunakan sumur bor. Namun penggunaan sumur bor tersebut masih dalam tingkatan rumah tangga, jadi dapat dikatakan masih aman, sehingga kestabilitasan air di lingkungan tersebut masih dapat terjaga dengan baik. Dengan demikian, maka penggunaan atau pengambilan air yang dilakukan perusahaan berdasarkan wawancara tersebut dapat dikatakan tidak mengganggu baik kondisi air di lingkungan sekitar maupun mengurangi jumlah air yang telah dipakai warga di luar perumahan islami tersebut. Namun, bagaimana dengan limbah perusahaan terhadap sumber air? Perusahaan sendiri mengakui memang ada limbah yang dihasilkan, seperti yang dijelaskan oleh Pak SO. Limbah merupakan faktor yang dapat menyebabkan berbagai macam polusi, yang tentu saja dapat menyebabkan kerugian bagi kehidupan, seperti kondisi udara menjadi tidak sehat, kondisi air di suatu tempat menjadi buruk dan sebagainya, yang dapat menyebakan kesehatan makhluk hidup di sekitarnya menjadi terganggu.

Perusahaan perumahan Islami mengenai limbah yang dihasilkannya, ternyata telah diperhitungkan secara matang. Hal ini dapat diketahui dari Pak SO seperti berikut:

"Limbah campuran dari semen sama pasir,

dan kita pun pekerjaannya diatas tanah

kavling, jadi tidak sampai ke gorong-gorong,

tidak sampai menuju ke saluran air warga.

Jadi diusahakan jauh dari sumber air."

Berdasarkan hasil wawancara tersebut maka perusahaan telah memperhitungkan mengenai limbah yang dihasikannya, yaitu berupa limbah dari campuran semen dan pasir. Oleh karena itu, mereka telah memperhitungkan caranya, yaitu diusahakan agar jauh dari sumber air, sehingga tidak sampai masuk ke gorong-gorong yang telah dibuat tadi, apalgi sampai menuju ke saluran air warga di luar 
perumahan. Meskipun dapat dikatakan jika limbah yag dihasilkan oleh perusahaan jumlahnya tidak banyak, namun tetap saja jika limbah tersebut masuk ke saluran air dapat menyebabkan bahaya.

\section{Pemanasan Global}

Perumahan Islami DP melalui Pak SO menyadari jika pemanasan global disebabkan oleh efek rumah kaca, oleh karena itu perusahaan menawarkan adanya panel surya sebagai bahan yang hemat energi untuk pemanas air di dalam unit perumahannya. Namun tidak semua unit di dalam perumahan itu menggunakan panel surya. Hal ini karena tergantung permintaan dari pengguna atau penghuni warga perumahan tersebut. Berikut yang dinyatakan oleh Pak SO mengenai usaha perusahaan mencegah timbulnya efek rumah kaca sehingga dapat menyebabkan terjadinya pemanasan global:

"Global warming itu kalau di bidang konstruksi dikarenakan efek rumah kaca, jadi disini kita masih menggunakan standar umum. Lalu menyerankan pihak user, katakanlah misalkan di perumahan kan ada penambahan pemanas air, itu ada tiga cara, menggunakan gas LPG, listrik bisa juga menggunakan panel surya. Jadi kita sarankan yang beanrw hemat energi dan berkualitas. Panel surya saya rasa hemat energi dia. Tergantung usernya, dan tergantung budgeting."

Panel surya merupakan alat yang difungsikan untuk mengubah energi matahari menjadi listrik. Dalam panel surya ini terdapat sel surya yang memiliki fungsi untuk memaksimalkan sinar matahari atau cahaya matahari. Sel surya sendiri merupakan perangkat listrik yang didalamnya terdapat sel fotovoltaik yang memiliki fungsi untuk merubah energi dari cahaya matahari secara langsung menjadi listrik. Jadi cara kerja dari panel surya ini adalah mengumpulkan panas dari cahaya matahari lalu digunakan untuk memanaskan cairan, kemudian uapa yang dihasilkan dipnasakan oleh generator, sehingga dapat menghasilkan listrik.

Panel surya memiliki keuntungan, diantaranya adalah turut mengurangi pemanasan global, karena sistem panel surya menghasilkan energi yang ramah lingkungan. Hal ini disebabkan panel surya hanya menggunakan panas dari cahaya matahari sebagai sumber penghasil listriknya. Berbeda halnya dengan penggunaan bahan bakar fosil yang dapat menghasilkan efek rumah kaca, sehingga memperbesar terjadinya pemanasan global. Dengan demikian, yang dilakukan oleh perusahaan sangatlah tepat karena menawarkan pemasangan panel surya sebagai pemanas air bagi warga perumahan. Meskipun perusahaan juga menyediakan gas dan listrik juga sebagai pemanas air karena hal itu tergantung dari permintaan dari warga perumahan tersebut.

\subsection{Dimensi Spiritual: Upaya Membentuk Akhlakul Karimah}

Perusahaan memiliki aturan untuk melaporkan sholat ini dengan meminta para karyawan untuk membuat pencatatan. Terutama bagi laki-laki, perusahaan sangat mengharapkan jika mereka melaksanakan sholat berjamaah di masjid. Hal ini dapat diketahui dari wawancara peneliti dengan Pak DN sebagai berikut:

"Mewajibkan karywan sholat 5 waktu terutama laki-laki kita sangat mengharapkan di masjid, kita mintai record-nya. Setiap satu pekan sekali ada meeting, melaporkan planning, aktivitasnya, kegiatan sholatnya, kita pantau, sholatnya kita utamakan"

Maksud adanya record atas sholat yang dilakukan memang dapat menimbulkan bermacammacam pemikiran. Mungkin ada yang berpikir jika itu diterapkan oleh perusahaan, maka bisa jadi karyawan akan terpaksa melakukan sholat berjamaah di di masjid terutama bagi yang laki-laki, sehingga sholat berjamaah di masjid tersebut seperti bukan ikhlas lillahi ta'ala, melainkan adanya record tersebut. Namun, perlu ditekankan disini, masalah ikhlas atau tidak ikhlas merupakan suatu hal yang tidak bisa orang lain nilai, yang bisa menilai hanyalah Allah SWT dan orang itu sendiri. Selain itu, maksud dari adanya pencatatan atas kegiatan sholat tersebut dapat menimbulkan beberapa manfaat, diantaranya adalah para karyawan akan terbiasa melakukan sholat berjamaah terlebih lagi berjamaah di masjid dalam kehidupannya sehari-hari.

Kegiatan lain yang dilakukan oleh perusahaan agar senantiasa tidak terlena akan kemewahan (palsu) dunia adalah menyelenggarakan pengajian, TPQ, dan banyak kegiatan lain bagi para karyawannya. Sebagaimana yang dikatakan oleh Pak DN:

"Satu minggu sekali ada pengajian mingguan, untuk semua karyawan, kumpul semua, ada ustadznya" 
"Di perumahan, ada rutinitas pengajian, TPQ dan ada banyak kegiatan. Ada satu rumah khusus untuk imam yang hafidz. Imam mampu mengajar TPQ (Tempat Pendidikan Al-Qur'an). Ustadz tersebut membina lingkungan di perumahan"

Dalam wawancara dengan Pak DN, maka perusahaan memang benar-benar serius dalam upayanya membina para karyawannya agar tidak terlena dengan kemewahan (semu) dunia. Hal ini terbukti jika banyak kegiatan spiritual yang dilakukan perusahaan untuk menjaga para karyawannya. Dalam penyelenggarakan kegiatan tersebut, pihak perusahaan bekerja sama dengan salah satu organisasi penyelenggara kegiatan keagamaan, yaitu griya tilawah, seperti yang dikatakan oleh Pak DN yaitu pihak perusahaan dalam menyelenggarakan kegiatan kegamaan bekerja sama dengan griya tilawah.Dari griya tilawah disediakan ustadz yang telah ditentukan oleh pihak griya tilawah itu sendiri dalam mengisi kegiatan kegamaan di perusahaan perumahan tersebut.

Usaha lain dari pihak perusahaan perumahan dalam membina karyawannya adalah selain bekerja sama dengan griya tilawah, juga memfasilitasi satu unit rumah khusus untuk ustadz dari griya tilawah tersebut. Jadi satu unit rumah khusus tersebut benarbenar disediakan secara gratis oleh pihak perusahaan perumahan berdasarkan wawancara dengan Pak DN selaku direktur utama perusahaan tersebut. Dengan adanya fasilitas tersebut, maka dapat dikatakan jika perusahaan benar-benar berkomitmen untuk membentuk perusahaan yang beanr-benar sesuai dengan nilai Islam, dan tidak hanya sekedar memberi nama Islami pada nama perusahaan perumahan tersebut.

Harapan perusahaan perumahan dalam menyelanggarakan perngajian mingguan maupun TPQ, seperti yang diungkapkan oleh Pak DN:

"Diharapkan merealiisasikan dakwah, membentuk lingkungan islami, mulai orang tuanya bagus, anaknya bagus, harapnnya itu menjadi tabungan kita di akhirat nanti, jadi tidak murni untuk bisnis tapi kita utamanya adalah ingin dakwah"

"Selalu kita tekankan nanti antar warga itu bisa saling mengenal dengan baik, kan kebanyakan perumahan itu bahkan sesama tetangga aja tidak kenal. Dari awal kita sampaikan, perumahan kita ini perumahan yang guyub, warganya saling mengenal, makanya kita harapkan nanti masjid benarbenar hidup, artinya kalau semua warga sudah sholat di masjid, terutama yang lakilaki kan, mereka saling mengenal, ngajinya bagus, Timbul rasa empati sudah saling mengenal, nanti akan timbul tingkat kenyamanan, suasana dalam rumah itu dalam ruangan enak, semua saling mengenal, saling berinteraksi, saling menyapa, tidak sendirisendiri, tidak individualis...”

"Harapannya kita ini tidak ekslkusif, meskipun di masjid di dalam perumahan, namun bukan berarti hanya milik warga perumahan...kita akan merangkul masyarakat di sekitar sana, bagaimana kita bisa membina masyarakat disana. Kan masih banyak to masyarakat yang mungkin nggak pernah sholat, ndak pernah ngaji”

\section{KESIMPULAN}

Dari informasi yang penulis peroleh dari informan mengenai mengenai cara perusahaan menjalankan program keberlanjutannya dalam dimensi ekonomi diantaranya adalah perusahaan memberikan sebagian penghasilannya untuk membantu masyarakat yang membutuhkan di lingkungan perusahaan sekitar, (meskipun saat ini masih) sesuai dengan momen-momen tertentu. Lalu perusahaan juga berusaha untuk membantu perekonomian warga sekitar, dengan menerima karyawan dari warga sekitar tersebut melalui rekomendasi RW setempat dan tanpa ada kualifikasi khusus. Meskipun hanya pada posisi tertentu seperti pos satpam atau keamanan maupu untuk tenaga kebersihan, namun itu sangat membantu perekonomian bagi warga tersebut.

Dari segi sosial, perusahaan telah berusaha diantaranya adalah untuk memperhatikan kesejahteraan karyawan diantaranya dengan penyediaan klaim tanpa premi, sehingga tidak akan memotong gaji karyawan maupun sampai pemberian pelatihan maupun seminar. Begitupun dengan masyarakat sekitar, perusahaan mencoba untuk memberikan yang terbaik bagi mereka, misalkan tidak memberikan ijin adanya pekerja yang masih dibawah umur (sesuai apa yanga ada di dalam G3 reporting guidlines), adanya bantuan untuk kegiatan yang diselenggarakan oleh masyarakat. 


\section{Jurnal Ilmiah Ekonomi Islam, 7(02), 2021, 570}

Dari segi lingkungan, beberapa usaha perusahaan diantaranya adalah turut serta untuk mengurangi atau pun mencegah pemanasan global akibat efek rumah kaca, menawarkan kepada konsumen untuk menggunakan panel surya sebagai pemanas air. Selain itu, mematuhi aturan berupa bahan SNI yang digunakan dalam pembangunan, kemudian tidak menggunakan campuran yang meyelahi aturan dengan tujuan untuk hemat anggaran, serta memenuhi aturan ruang terbuka hijau (RTH) dan memperlakukan limbah agar kestabilitasan air terjaga sehingga tidak mengganggu kondisi persawahan masyarakat.

Dari segi spiritual, perusahaan sangat menekankan para karyawannya untuk menjaga kewajiban sholatnya, terutama untuk karyawan lakilaki yang di usahakan agar terus bisa sholat berjamaah. Selain itu, untuk menambah pengetahuan mereka, warga perumahan maupun masyarakat (umum) mengenai agama, diadakan kajian agama tiap minggunya di masjid perumahan

Penelitian ini diharapkan dapat memberikan pandangan bagi pihak perumahan syrariah atau perumahan Islami yang lain untuk mengambil kegiatan di perumahan islami yang dijadikan sebagai objek dalam peneltian ini yang belum ada di perumahannya, sehingga kekurangan maupun kelebihan yang ada di perumahan islami dialam penelitian ini, maupun perumahan syariah yang lain dapat saling memperbaiki maupun melengkapi satu sama lain. Hal ini akan berakibat terwujudnya perumahan Islami yang benar-benar islami dan bukan hanya sebagai strategi pemasaran agar perumahan menjadi lebih memiliki nilai jual. Wallahu A'lam Bishshowab

\section{DAFTAR PUSTAKA}

Chwastiak, M. (1999). Deconstructing the PincipalAgent Model: A View From the Bottom. Critical Perspectives on Accounting, 10, 425-441.

Dewi, I. G. A. A. O. (2010). Dialektika dan Refleksi Kritis realitas "Sustainability" Dalam Prakrik Sustainability Reporting: Sebuah Narasi Habermasian. Jurnal Akuntansi dan Keuangna Indonesia, $\operatorname{Vol} 7(2)$.

Efferin, S. (2015). Akuntansi, Spiritualitas dan Kearifan Lokal: Beberapa Agenda Penelitian Kritis. Jurnal Akuntansi Multiparadigma. Vol. 3(3), 466-480
Elkington, J. (1997). Cannibals with forks: The tripple bottom line of 21th century business. Oxford: Capstone Publishing Ltd.

Elkington, J. (2004). Enter the Tripple Bottom Line. Essay Triple Bottom Line, Vol.7 Chapter 1.

Felisia, \& Limijaya, A. (2014). Triplle Bottom Line dan Sustainability. Bina Ekonomi Majalah Ilmiah Fakultas Ekonomi Unpar. Vol 18(1).

Finch, N. (2005). The Motivations for Adopting Sustainability Disclosure. MGSM Working Paper No. 2005-17

Friedman, M. (1970). The Social responsibility of Business is to Increase its Profits. The New York Times Magazine.

Guo, Y. \& Yang, D.C. (2014). Sustainability Accounting Reporting: A Survey on 30 U.S. Dow-Jones Companies. International Journal of Accounting and Taxation, Vol 2(3).

Mitchell, M., Curtis, A., \& Davidson, P. (2008). Evaluating the process of triple bottom line reporting: increasing the potential for change. LocalEnvironment, Vol. 13 (2), 67-80.

Molisa, P. (2011). A Spiritual Reflection On Emancipation And Accounting. Critical Perspective on Accounting, 22, 453-484.

Smythe, K. R. (2014). An Historian's Critique of Sustainability. Culture Unbound, Vol 6, pp. 913929

Stenzel, P.L. (2010). Sustainability, the Tripple Bottom Line, and the Global Reportung Initiative. Global Edge Business Review. Vol. 4(6).

Sukoharsono, E. G. (2010). Metamorfosis Akuntansi Sosial dan Lingkungan: Mengkonstruksi Akuntansi Sustainabilitas Berdimensi Spiritualitas. Pidato Pengukuhan Guru Besar, Senin 13 Desember 2010, Universitas Brawijaya. Ulfatin, N. (2015). Metode Penelitian Kualitatif Di Bidang Pendidikan: Teori Dan Aplikasinya. Malang: MNC Publishing.

Zhang, X. (2015). Green real estate development in China: State of art and prospect agenda - A review. Renewable and Sustainable Energy Reviews, 47, 1-13.

Zhu, Y., \& Lin, B. (2004). Sustainable housing and urban construction in China. Energy and Buildings, 36, 1287-1297. 